\title{
Coughing Children in Family Practice and Primary Care - A Systematic Review On Prevalence, Aetiology and Prognosis
}

\author{
Milena Bergmann \\ Philipp University of Marburg \\ Jörg Haasenritter \\ Philipp University of Marburg \\ Dominik Beidatsch \\ Philipp University of Marburg \\ Sonja Schwarm \\ Philipp University of Marburg \\ Kaja Bartsch \\ Philipp University of Marburg \\ Stefan Bösner \\ Philipp University of Marburg \\ Paula Grevenrath \\ Philipp University of Marburg \\ Laura Schmidt \\ Philipp University of Marburg \\ Annika Viniol \\ Philipp University of Marburg \\ Norbert Donner-Banzhoff \\ Philipp University of Marburg \\ Annette Becker ( $\square$ Annette.Becker@staff.uni-marburg.de) \\ Philipp University of Marburg
}

\section{Research Article}

Keywords: Cough, children, primary care, prevalence, prognosis, aetiology, symptom evaluation

Posted Date: February 5th, 2021

DOI: https://doi.org/10.21203/rs.3.rs-154884/v1

License: (9) (1) This work is licensed under a Creative Commons Attribution 4.0 International License. Read Full License 


\section{Abstract}

Background: For evidence-based decision-making general practitioners need setting specific knowledge on the pre-test probabilities of underlying diseases and a symptom's course. We performed a systematic review on symptom evaluating studies in primary care to give evidence on the prevalence, aetiologies and prognosis of coughing children who consult primary care settings.

Methods: Following a pre-defined algorithm and independent double reviewer ratings we searched MEDLINE and EMBASE. We included data from all quantitative original research articles in English, French or German assessing unselected study populations of children consulting for cough in primary care. We used the random effects model for meta-analysis in eligible subgroups if comprehensive in terms of heterogeneity.

Results: We identified 14 eligible studies on prevalence, five on aetiology and one on prognosis. Prevalence estimates varied between $4.7 \%$ and $23.3 \%$ of all reasons for encounter or up to estimates of $60 \%$ when related to patients or consultations. Cough in children is more frequent than in adults with lowest prevalences in adolescents and in summer. Acute cough is mostly caused by upper respiratory tract infections $(62.4 \%)$ and bronchitis (33.3\%); subacute or chronic cough by recurrent respiratory tract infection (27.7\%), asthma (3\% in cough of all durations to $50.4 \%$ in more than 3 weeks cough), and pertussis (37.2\%). Potentially serious diseases like croup, pneumonia or tuberculosis are scarce. In children with subacute and chronic cough the total duration of cough ranged from 24 to 192 days. About $62.3 \%$ of children suffering from prolonged cough are still coughing two months after the beginning of symptoms. We found strong heterogeneity across studies and only five studies with an overall low risk of bias.

Conclusion: Cough is one of the most frequent reasons of encounter in primary care. Our findings on aetiologies and prognosis fit in with current guideline recommendations supporting a thoughtful wait-and-see approach in acute cough and a special awareness of asthma in chronic cough. There is a remarkable high pre-test probability of pertusssis in children with cough of more than two weeks' duration. To develop primary-care cough guidelines symptom-evaluating studies assessing setting and age specific aetiologies and prognosis of cough are needed.

\section{Background}

Cough is a frequent reasons for encounter for both children ${ }^{1,2}$ and adults ${ }^{3}$ in ambulatory care. It often gives serious concern to parents ${ }^{4,5}$. Especially when prolonged, cough impairs daily activities or sleep and children's and caregivers' quality of life $2,6,7$. Therefore, $30 \%$ to $40 \%$ of coughing children consult a physician ${ }^{8}$.

General practitioners (GPs), family physicians or paediatricians triage self-limiting, prolonged, and potential life-threatening courses. In this respect assumed or research based pre-test probabilities and prognosis drive GPs' decision making and action.

Current guideline recommendations are mainly based on secondary or tertiary care studies ${ }^{9,10}$, which not necessarily conform with the situation in primary care. We therefore aimed for a systematic literature review on studies evaluating the prevalence, aetiologies and prognosis of cough in children consulting primary care settings.

\section{Methods}

We performed a systematic review of symptom-evaluating studies. Methods - based on the PRISMA statement ${ }^{11}$ and the recommendation of Donner-Banzhoff ${ }^{12}$ et al. - were pre-specified in a protocol. Our working group applied the same methods on abdominal pain, tiredness, chest pain, dizziness and dyspnoea ${ }^{13-17}$.

\section{Data sources and search strategy}

We searched MEDLINE in June 2012, updated 2019, and EMBASE in January 2015, updated 2020. The reference lists of all relevant papers were screened (snowball search). Our search was limited to publications in English, French, and German. The search syntax comprised the term "cough" in all possible wordings in title/abstract OR as MeSH Term, and the term "primary care" in all possible wordings in title/abstract OR in mail address or name of the authors's institute OR as MeSH Term OR a journal representing primary care research. For the entire search syntax see Additional file 1.

\section{Study selection and inclusion/exclusion criteria}


We first screened titles and abstracts with respect to (1) original research article, (2) primary care as study setting, and (3) reason for encounter "cough" (primary or secondary reason for consultation).

The full text publications were assessed for our inclusion criteria as above plus (4) an unselected study population regarding the likelihood of the underlying aetiology, and (5) data available on incidence, prevalence, underlying diagnoses or prognosis of cough. All criteria had to be fulfilled. We excluded qualitative studies, case reports, reviews, studies without available full text, and studies recruiting in secondary or tertiary care, emergency departments/out-of-hours-services or population-based settings. No studies with patients systematically asked about cough were included. To avoid pre-selection, we did not consider studies that excluded patients with chronic diseases; studies, which recruited patients with an increased probability for a particular diagnosis or with cough being part of a required symptom combination (e.g. cough plus fever or expectoration). We only included studies on children. Reasons for exclusion were documented.

The selection process was performed by two independently working reviewers: MB/DB or MB/SS (except the search update 2019/2020). In case of disagreement, reviewers discussed their ratings or, secondly, consulted a third reviewer (AB).

\section{Data extraction}

For each publication, we extracted bibliographic information (author, publication year, title, journal), country, inclusion/exclusion criteria, definition of cough, characteristics of physicians and practices, type of recruitment, information on study population (sample size, age, gender distribution) and study duration.

For prevalence/incidence data, we extracted the number of cough cases and the number and type of the reference study sample. For aetiology we registered all diagnostic categories with their relative and absolute frequencies, and we extracted any kind of prognostic data. We analysed all available publications of each study, and in doubt contacted the authors personally $(n=7)$.

\section{Assessment of methodical quality and risk of bias}

Our working group developed a literature based tool for evaluation of risk of bias and clinical heterogeneity in symptom studies ${ }^{12,18}$. A validation study is still running. Two reviewers $(\mathrm{KH}, \mathrm{MB})$ assessed independently 16 items in four key domains (Additional file 2 a) and rated the risk of bias in patient selection, data collection/patient flow, and in diagnostic and prognostic work-up. The risk of substantial variation/clinical heterogeneity was judged.

\section{Statistics}

Proportions on prevalence/incidence and underlying aetiologies plus $95 \%$ confidence interval were calculated. Study outcomes refer to different reference parameters as denominators (e.g. consultations, reasons for encounters or patients), We grouped studies by these denominators, by duration of cough (pre-specified) and regional characteristics (post hoc). Aetiological and prognostic outcomes were analysed descriptively. Probability estimates and between-study-variation are visualized with forest plots. For meta-analysis, we used the random-effects model (for distribution across studies) ${ }^{19}$.

Study outcomes vary due to methodical (study design and bias) and clinical heterogeneity (study population, inclusion criteria, health care system, diagnostic work-up) ${ }^{19}$. We used $\chi^{2}$, p-value and $\mathrm{I}^{2}::$ A heterogeneity beyond chance is characterized by high values of $\chi^{2}$ and low $\mathrm{p}$ values; the portion of variability that is not due to chance is marked by $\mathrm{I}^{219}$.

We used the software R (R Foundation for statistical Computing, Vienna, Austria, version 3.4.4) and RStudio V (RStudio, Inc., version 1.1.442).

\section{Results}

We identified 5704 records (2985 in MEDLINE and 2719 in EMBASE) after removal of duplicates plus 19 records from snowballing, 73 papers fulfilled our inclusion criteria after full text screening, only 19 studies focussed on children. Of these, 14 studies provided data on the cough prevalence, five on underlying aetiologies and one study on prognostic outcomes (see Fig. 1).

\section{Included studies}


Most studies were conducted in Europe $(n=10)$, followed by North America $(n=3)$, Australia $(n=1)$, Africa $(n=4)$, and Asia $(n=1)$. Studies were published between 1971 and 2019. Mostly, data was assessed prospectively. The study populations consisted of 121 to 5100 patients, 188 to 92888 consultations, 1196 to 70489 reasons for encounters and 3371 episodes of care. Female patients ranged from $45 \%$ to $54 \%$, mean age varied from 18.4 months to 9.8 years. Only three studies included children of all age groups (one study including some adults consulting paediatric offices). Solely children $<5 /<6 /<7$ years were included in five studies, solely children $\geq 5$ years in two studies. Nine studies excluded children $>11 />14 />15$ years of age. Data was accrued by 1-209 primary care paediatricians or GPs in 1-57 paediatric or general practices. Further details on the included studies are given in Table 1.

\section{Assessment of methodical quality and risk of bias}

We found a high risk of substantial variation/clinical heterogeneity in the majority of studies $(n=11)$, mostly because certain age groups were excluded (domain A). The risk of selection bias of patients was low, high and unclear in about a third of studies each. Concerning data collection (domain $B$ ), most studies had a low risk of bias $(n=14)$, none a high risk. The risk of bias in diagnostic work-up (domain $C)$ was high in three studies, low in one and unclear in another. There was only one study with prognostic outcomes, showing a low risk of bias in prognostic work-up (domain D). Only five studies showed an overall low risk of bias. For details please see Additional file 2 a-d and Additional file 3.

\section{Prevalence}

Fourteen studies commented on prevalence or incidence of cough, five of these had an overall low risk of bias ${ }^{21,26,27,32,35}$ (Additional file 2b). Depending on nominators and denominators, results are grouped in four categories. Five studies referred to all patients suffering from cough in relation to all consultations (patients consulting their physician several times are counted more than once), four present prevalences in relation to the number of patients. In both groups prevalence ranges from $7.9^{21}$ to $61.2^{22}$ Precision of results is best when referring to studies on cough related to reasons for encounter. This includes physician consultations as well as consultations for prescriptions, follow-up visits, tests, procedures and administrative visits ${ }^{34}$. Prevalences range from $4.7^{34}$ to $23.3^{28}$. Forrest plots and measures of heterogeneity are given in Additional file 4. Seasonal effects can be seen in studies recruiting solely in European winter season showing high estimates ${ }^{22,26}$, while studies taking place in Italian spring/summer and Ethiopian August showing low estimates ${ }^{21,36}$. Studies on older children show comparably low prevalences ${ }^{32,35}$. Morrell et al. found a one-year cough rate of 267 (male) resp. 238(female) per 1000 patients at risk (0-4 years) and 113 (female) resp. 160 (male) for children aged 5-14 yeas ${ }^{30}$. Age subgroup analyses didn't minimize the high heterogeneity across studies. We did a subgroup analysis for regional characteristics which showed comparable estimates for consultations, reasons for encounters, and patients in Western countries (see Fig. 2).

Because only one study showed a low overall risk of bias and a low concern of clinical heterogeneity a subgrouping by quality was not possible ${ }^{35}$.

\section{Aetiologies}

Five studies presented prevalence data on aetiology. Except for Harnden 2006 who excluded children $<5$ years, the studies included all age groups. As outcomes referred to different durations of cough, we omitted meta-analysis and presented the data descriptively (see Table 2). The most frequent aetiology is upper respiratory tract infection, followed by bronchitis in acute cough, and recurrent respiratory tract infection, asthma and pertussis in subacute and chronic cough. Estimates of frequencies are lower when related to episodes of care (Transition ${ }^{37}$ ) compared to consultations $\left(K_{\text {Krishnan }}^{25}\right.$ ), when patients may be counted more than once. There is a high prevalence of pertussis in children coughing for more than two weeks, confirmed by serological evidence ${ }^{24}$. In all other studies aetiologies based on GPs' working diagnoses ${ }^{31,37,39}$ or the diagnostic work-up was unclear ${ }^{25}$, which is attended by a high or unclear risk of bias. No study presented with an overall low risk of bias.

\section{Prognosis}

Only one study reported prognostic outcomes.: In 18 practices in the United Kingdom, Harnden et al. recruited 179 children aged 5 to 16 years who had been coughing for 14 days or more ${ }^{24}$. Participants completed a daily cough diary for two weeks, then a weekly diary for its duration. The total duration of cough ranged from 24 to 192 days (median duration was 112 days/resp. 58 days for patients with a 
positive/resp. negative pertussis serology). After two months $62,3 \%$ of children were still coughing (positive pertussis serology: $85 \%$, negative pertussis serology: $49 \%$ ).

\section{Discussion}

\section{Summary}

Our systematic review identified 19 eligible studies. Prevalence estimates varied widely between $12 \%$ (of reasons for encounter) and up to $45 \%$ (of patients) in Western countries. We found differential effects with lower prevalences in summer and in older children. Whereas acute cough is mostly caused by infectious diseases like upper respiratory tract infection (RTI) or bronchitis, up to every second case of subacute/chronic cough goes back on asthma. It is likely that there is a high number of unreported cases suffering from Pertussis in children with prolonged cough of at least 14 days. Potentially serious diseases like pneumonia or tuberculosis are scarce. Duration of cough varies widely, in subacute/chronic cough $62.3 \%$ of children are still coughing after two months.

\section{Strengths and limitations}

Sources of potential bias in systematic reviews are (1) criteria affecting the internal validity of studies (imprecise inclusion criteria and incomplete recruitment of study population), (2) limitations to the external validity of studies (setting characteristics and recruitment practice compromising the generalizability and applicability of the results), (3) methodological factors affecting the review's internal validity (accuracy in literature search, screening process and data analysis), and (4) limitations to the review's external validity 16,17,40.

To control these factors, we performed a substantial search and stated clear inclusion and exclusion criteria. We omitted specialised paediatric journals or the term "paediatric practice” in our syntax, but we expect the misclassification to be low due to the comprehensive search on primary care settings including primary care paediatricians. We explicitly excluded studies from secondary/tertiary care or paediatric outpatient departments and did a double reviewer screening. Selection bias was minimized by considering only unselected study populations: In case of missing data regarding eligibility criteria we contacted study authors. Though, in some cases uncertainty remained. We performed a strict and standardized assessment of methodical quality, clinical heterogeneity and risk of bias ${ }^{12}$. Given the small number of included studies, we didn't control for risk of bias across studies. Also publication bias is unlikely, since we suppose it improbable that prevalences, aetiologies or prognosis wouldn't be published.

We found substantial methodological and clinical heterogeneity across age groups, study settings, health care systems, duration of cough, outcomes and reference parameters. Furthermore, cultural variables or gate keeping influence the threshold to consult the doctor which is why we included only studies recruiting in primary care settings. Still, age distribution in study samples may affect results: In German general practices over $50 \%$ of the study population were $15-19$ years of age ${ }^{35}$, while in two Italian family paediatricians' offices $61-73 \%$ of children were $<6$ years ${ }^{21,22}$. In fact, its impact seems to be low, since heterogeneity was not minimized by age related subgroups. The biggest limit to our study probably is the scarcity of high quality studies.

\section{Comparison with existing literature}

Indeed, reviews report coughing as one of the most common reasons for consultation in routine paediatric and family practice ${ }^{2,41}$. The majority of children experience 5 to 8 episodes of one week caught throughout the year ${ }^{41}$. But these studies are mostly based on secondary/tertiary care data ${ }^{42,43}$ or population based ${ }^{44}$. Age influences the development of the respiratory system in general ${ }^{45}$, which explains the change of prevalences over lifetime and distinctive age-related patterns ${ }^{44}$ as shown in our study with lowest cough prevalences in studies on mainly older children $\left(51,2 \%\right.$ of children aged 15 to 19 years $\left.{ }^{35}\right)$. This is in accordance with the guidelines of the American College of Chest Physicians who set the cut-off age to apply adult protocols at 14 years of age ${ }^{11,46}$.

The distinction between acute, subacute and chronic cough differs from that used in adults ${ }^{46-49}$. The US and Australian-New Zealand guidelines define acute cough in children to last $<2$ weeks, subacute cough 2-4 weeks and chronic cough $>4$ weeks. This is based on the natural course of upper RTI in children 9,50 differing to the one in adults ( $<3$ weeks, 3-8 weeks and $>8$ weeks) ${ }^{7}$. Triaging patients according the duration of cough is the first step in the diagnostic process, which is why aetiological data for both acute and chronic cough are required. Though, the categorizations in the identified studies differed from those suggested in the cough guidelines ${ }^{24,31}$. 
Acute cough in children is mostly caused by upper RTI and bronchitis, which is confirmed by the current literature $2,7,51$. Its self-limiting course justifies a "wait-and-see" strategy, if no warning signs are present. This is different for chronic cough with a high prevalence of asthma and pertussis. Studies conducted in hospitals confirmed the importance of asthma in chronic cough $42,43,52$ and current guidelines highlight asthma as frequent cause of disease. Our data suggest that the risk of asthma increases with the duration of cough. This explains why studies including patients with all durations of cough ${ }^{27,37}$ show much lower rates than a sample with a minimum of a three weeks' symptom duration ${ }^{31}$. However, further studies are needed to provide the exact thresholds in time for clinical relevant increase of risk. The prevalence and consequently the two weeks' pre-test probability of pertussis turned out to be very high, found in a multicentre study in the UK with low rik of bias. Physicians should be aware of this.

We know from secondary care studies that acute cough caused by upper RTI lasts about 5.18 days (follow-up 6 days) in children ${ }^{53}$. For the primary care setting acute cough seems to resolve in half of children within one week, in $10-20 \%$ of children by three weeks ${ }^{51,54}$. The methodological quality of these studies is low. ${ }^{51,54}$. Terms like "acute cough", "acute bronchitis" or "chest infection" are often used simultaneously for different signs and symptoms ${ }^{55}$. Therefore, authors claim prognostic studies in primary care based on symptoms ${ }^{54,55}$ with a sufficient long follow-up period and an unselected patient population.

\section{Conclusions}

Prevalence of cough is higher in younger children than in adolescents and lowest in summer. The high prevalence of upper RTI as underlying disease and the low prevalence of potential serious illnesses justifies a "wait and see"-approach in acute cough. Evidence on prolonged cough is scarce, but the prevalence of asthma and pertussis seem to rise substantially up to every second child suffering from asthma ( 1 in 5 from pertussis) in subacute or chronic cough. Other serious diseases like pneumonia or tuberculosis are less than $0.5 \%$. There is hardly any data on prognosis of cough of children. To ensure evidence-based decision-making there is a great need for further high quality studies. symptom evaluating studies on children's cough with a special focus on primary care.

\section{Abbreviations}

GP - General Practitioner

RTI - Respiratory tract infection

\section{Declarations}

\section{Ethical approval: Not applicable}

Consent for publication: Not applicable

Availability of data and materials: All data analysed during this study are drawn from published articles. The respective references and extracted numbers are all included in this article and its supplementary data files.

Competing interests: The authors declare that they have no competing interests.

Funding: This work was supported by own resources of the Department for primary care, University of Marburg.

Authors' contributions: M.B., J.H., D.B., S.Sch., K.B., S.B., P.G., L.S., A.V., N.DB., and A.B. participated in the study design and analyses. M.B. A.B., and J.H. performed and wrote a first draft of the manuscript. J.H., S.Sch., P.G., L.S., K.B., S.B., D.B., N.DB., and A.V. commented on this draft and performed critical revisions. All authors have read and approved the manuscript.

Acknowledgements: We would like to thank Thomas Frese for providing information and data.

\section{References}

1. Fegeler U, Jager-Roman E, Martin R, Nentwich H-J. Pediatric primary healthcare: Health services study of the German Academy for Child and Adolescent Medicine. [German]. Monatsschrift fur Kinderheilkunde. 2014;162:1117-30.

2. Lamas A, Ruiz de Valbuena M, Máiz L. Cough in Children. Arch Bronconeumol. 2014;50:294-300.

3. Hsiao C-J, Cherry DK, Beatty PC, Rechtsteiner EA. National Ambulatory Medical Care Survey: 2007 summary. Nat Health Stat Report. 2010:1-32. 
4. Cornford CS, Morgan M, Ridsdale L. Why do mothers consult when their children cough? Fam Pract. 1993;10:193-6.

5. Ramanuja S, Kelkar PS. The approach to pediatric cough. Ann Allergy Asthma Immunol. 2010;105:3-8; quiz 9-11, 42.

6. Marchant JM, Newcombe PA, Juniper EF, Sheffield JK, Stathis SL, Chang AB. What Is the Burden of Chronic Cough for Families? Chest. 2008;134:303-9.

7. Shields MD, Bush A, Everard ML, McKenzie S, Primhak R. Recommendations for the assessment and management of cough in children. Thorax. 2008;63 Suppl 3:iii1-iii15.

8. Hay AD, Heron J, Ness A. The prevalence of symptoms and consultations in pre-school children in the Avon Longitudinal Study of Parents and Children (ALSPAC): a prospective cohort study. Fam Pract. 2005;22:367-74.

9. Chang AB, Glomb WB. Guidelines for Evaluating Chronic Cough in Pediatrics. Chest. 2006;129:260S-283S.

10. Chang AB, Oppenheimer JJ, Weinberger M, et al. Etiologies of Chronic Cough in Pediatric Cohorts: CHEST Guideline and Expert Panel Report. Chest. 2017;152:607-617.

11. Moher D, Liberati A, Tetzlaff J, Altman DG. Preferred reporting items for systematic reviews and meta-analyses: The PRISMA statement. PLoS Med. 2009;6:e1000097.

12. Donner-Banzhoff N, Kunz R, Rosser W. Studies of symptoms in primary care. Fam Pract. 2001;18:33-38.

13. Viniol A, Keunecke C, Biroga T, Stadje R, Dornieden K, Bösner S et al. Studies of the symptom abdominal pain-a systematic review and meta-analysis. Fam Pract. 2014;31:517-29.

14. Stadje R, Dornieden K, Baum E, Becker A, Biroga T, Bösner S et al. The differential diagnosis of tiredness: a systematic review. BMC Fam Pract. 2016;17:147.

15. Haasenritter J, Biroga T, Keunecke C, Becker A, Donner-Banzhoff N, Dornieden K et al. Causes of chest pain in primary care-a systematic review and meta-analysis. Croat Med J. 2015;56:422-30.

16. Bösner S, Schwarm S, Grevenrath P, Schmidt L, Hörner K, Beidatsch D et al. Prevalence, aetiologies and prognosis of the symptom dizziness in primary care - a systematic review. BMC family practice. 2018;19:33.

17. Viniol A, Beidatsch D, Frese T, Bergmann M, Grevenrath P, Schmidt L et al. Studies of the symptom dyspnoea: a systematic review. BMC Fam Pract. 2015;16:152.

18. Richardson WS, Wilson MC, Guyatt GH, Cook DJ, Nishikawa J. Users' guides to the medical literature: XV. How to use an article about disease probability for differential diagnosis. Evidence-Based Medicine Working Group. JAMA. 1999;281:1214-9.

19. Higgins JPT, Thomas J, Chandler J, Cumpston M, Li T, Page MJ et al. Cochrane Handbook for Systematic Reviews of Interventions. 2019. Available at: www.training.cochrane.org/handbook. Accessed 24 Jan 2021.

20. Boyce SP, Nyangara F, Kamunyori J. A mixed-methods quasi-experimental evaluation of a mobile health application and quality of care in the integrated community case management program in Malawi. Journal of global health. 2019;9:10811.

21. Cazzato T, Pandolfini C, Campi R, Bonati M. Drug prescribing in out-patient children in Southern Italy. Eur J Clin Pharmacol. 2001;57:611-6.

22. Giannattasio A, Lo Vecchio A, Napolitano C, Di Florio L, Guarino A. A prospective study on ambulatory care provided by primary care pediatricians during influenza season. Ital J Pediatr. 2014;40:38.

23. Hall KK, Chang AB, Anderson J, Dunbar M, Arnold D, O'Grady K-AF. Characteristics and respiratory risk profile of children aged less than 5 years presenting to an urban, Aboriginal-friendly, comprehensive primary health practice in Australia. J Paediatr Child Health. 2017;53:636-643.

24. Harnden A, Grant C, Harrison T, et al. Whooping cough in school age children with persistent cough: prospective cohort study in primary care. BMJ. 2006;333:174-7.

25. Krishnan S, lanotti V, Welter J, Gallagher MM, Ndjatou T, Dozor AJ. Bronchodilators, Antibiotics, and Oral Corticosteroids Use in Primary Care for Children With Cough. Global pediatric health. 2019;6:2333794X19831296.

26. Leconte S, Degryse J. Prolonged cough in children in the primary care office. Rev Med Brux. 2011;32:5-9.

27. Mash B, Fairall L, Adejayan O, Ikpefan O, Kumari J, Matheel S et al. A morbidity survey of South African primary care. PLoS One. 2012;7:e32358.

28. Molony D, Beame C, Behan W, Crowley J, Dennehy T, Quinlan M, Cullen W. 70,489 primary care encounters: Retrospective analysis of morbidity at a primary care centre in Ireland. Ir J Med Sci. 2016;185:805-811.

29. Morrell DC, Gage HG, Robinson NA. Symptoms in general practice. J R Coll Gen Pract. 1971;21:32-43.

30. Morrell DC. Symptom interpretation in general practice. J R Coll Gen Pract. 1972;22:297-309.

31. Movsowitz L. Chronic cough and cough mixtures in a private paediatric practice. S Afr Med J. 1987;71:573-4.

Page 7/17 
32. Schappert SM, Nelson C. National Ambulatory Medical Care Survey: 1995-96 summary. Vital Health Stat 13. 1999; Series 13, Data from the National Health Survey (142):i-vi, 1-122.

33. Nizami SQ, Khan IA, Bhutta ZA. Paediatric prescribing in Karachi. J Pak Med Assoc. 1997;47:29-32.

34. Njalsson T, McAuley RG. Reasons for contact in family practice. An Icelandic multicentre study on content of practice. Scand J Prim Health Care. 1992;10:250-256.

35. Frese T, Klauss S, Herrmann K, Sandholzer H. Children and adolescents as patients in general practice - the reasons for encounter. J Clin Med Res. 2011;3:177-82.

36. Simoes EA, Desta T, Tessema T, Gerbresellassie T, Dagnew M, Gove S. Performance of health workers after training in integrated management of childhood illness in Gondar, Ethiopia. Bull World Health Organ. 1997;75 Suppl 1:43-53.

37. Okkes IM, Oskam SK, Lamberts $\mathrm{H}$. The probability of specific diagnoses for patients presenting with common symptoms to Dutch family physicians. J Fam Pract. 2002;51:31-36.

38. Usherwood TP. Development and randomized controlled trial of a booklet of advice for parents. Br J Gen Pract. 1991;41:58-62.

39. Vinson DC, Lutz LJ. The effect of parental expectations on treatment of children with a cough: a report from ASPN. J Fam Pract. 1993;37:23-27.

40. Cochrane Deutschland, Arbeitsgemeinschaft der Wissenschaftlichen Medizinischen Fachgesellschaften - Institut für Medizinisches Wissensmanagement. Bewertung des Biasrisikos (Risiko systematischer Fehler) in klinischen Studien: ein Manual für die Leitlinienerstellung. [Evaluation of risk of bias (ris of systematic bias) in clinical studies: a manual for guideline development] 2016. http://www.cochrane.de/de/rob-manual; AWMF: http://www.awmf.org/leitlinien/awmf-regelwerk/Il-entwicklung.html. Accessed 24 Jan 2021.

41. Ptak K, Cichocka-Jarosz E, Kwinta P. Chronic Cough in Children. Developmental period medicine. $2018 ; 22$.

42. Marchant JM, Masters IB, Taylor SM, Cox NC, Seymour GJ, Chang AB. Evaluation and outcome of young children with chronic cough. Chest. 2006;129.

43. Chang AB, Robertson CF, van Asperen PP, Glasgow NJ, Mellis CM, Masters IB et al. A Multicenter Study on Chronic Cough in Children. Chest. 2012;142:943-950.

44. Jurca M, Ramette A, Dogaru CM, Goutaki M, Spycher BD, Latzin P et al. Prevalence of Cough Throughout Childhood: A Cohort Study. PloS one. 2017;12.

45. Chang AB, Widdicombe JG. Cough Throughout Life: Children, Adults and the Senile. Pulmonary pharmacology \& therapeutics. 2007;20.

46. Irwin RS, French CL, Chang AB, Altman KW. Classification of Cough as a Symptom in Adults and Management Algorithms: CHEST Guideline and Expert Panel Report. Chest. 2018;153:196-209.

47. Irwin RS, Baumann MH, Bolser DC, Boulet LP, Braman SS, Brightling CE et al. Diagnosis and management of cough executive summary: ACCP evidence-based clinical practice guidelines. Chest. 2006;129 Suppl 1:1S-23S.

48. Kohno S, Ishida T, Uchida Y, Yoshyuki KH, Sasaki H, Shioya T et al. The Japanese Respiratory Society guidelines for management of cough. Respirology. 2006;11 Suppl 4:S135-86.

49. Lai K, Shen H, Zhou X, et al. Clinical Practice Guidelines for Diagnosis and Management of Cough-Chinese Thoracic Society (CTS) Asthma Consortium. J Thorac Dis. 2018;10:6314-51.

50. Chang AB, Landau LI, Van Asperen PP, Glasgow NJ, Robertson CF, Marchant JM et al. Cough in children: Definitions and clinical evaluation. The Medical journal of Australia. 2006;184.

51. Hay $A D$, Wilson $A D$. The natural history of acute cough in children aged 0 to 4 years in primary care: a systematic review. Br $\mathrm{J}$ Gen Pract. 2002;52:401-9.

52. Asilsoy S, Bayram E, Agin H, Apa H, Can D, Gulle S, Altinoz S. Evaluation of chronic cough in children. Chest. 2008;134.

53. Oduwole O, Udoh EE, Oyo-Ita A, Meremikwu MM. Honey for acute cough in children. The Cochrane database of systematic reviews. 2018;4.

54. Hay AD, Wilson A, Fahey T, Peters TJ. The duration of acute cough in pre-school children presenting to primary care: a prospective cohort study. Fam Pract. 2003;20:696-705.

55. Stocks N, Fahey T. Labelling of acute respiratory illness: Evidence of between-practitioner variation in the UK. Fam Pract. 2002;19:3757.

\section{Tables}


Table 1: Description of the included studies

Page 9/17 


\begin{tabular}{|c|c|c|c|c|c|c|c|c|}
\hline Studies & Country & Setting & $\begin{array}{l}\text { Time of } \\
\text { recruit- } \\
\text { ment }\end{array}$ & $\begin{array}{l}\text { Data assess- } \\
\text { ment }\end{array}$ & $\begin{array}{l}\text { Study } \\
\text { population: } \\
\text { number } \\
\text { female }\end{array}$ & $\begin{array}{l}\text { Age in } \\
\text { study } \\
\text { sample } \\
\text { (years }^{1} \text { ) }\end{array}$ & $\begin{array}{l}\text { Inclusion (IN) / } \\
\text { Exclusion (EX) } \\
\text { criteria }\end{array}$ & $\begin{array}{l}\text { Out- } \\
\text { come }\end{array}$ \\
\hline $\begin{array}{l}\text { Boyce } 2019 \\
20\end{array}$ & Malawi & $\begin{array}{l}57 \text { health } \\
\text { facilities with } \\
250 \text { health } \\
\text { surveillance } \\
\text { assistants for } \\
\text { integrated } \\
\text { community } \\
\text { case } \\
\text { management }\end{array}$ & n.r. & prospectively & $\begin{array}{l}987 \text { children } \\
\square 52 \%\end{array}$ & $\begin{array}{l}\varnothing 23.4 \\
\text { months }\end{array}$ & $\begin{array}{l}\text { IN: first } 4 \\
\text { children, aged } \\
2-59 \text { months, } \\
\text { presenting to } \\
\text { the health } \\
\text { surveillance } \\
\text { assistants for } \\
\text { an initial } \\
\text { consultation of } \\
\text { their current } \\
\text { illness } \\
\text { EX: severely ill } \\
\text { children who } \\
\text { needed urgent } \\
\text { referral to a } \\
\text { health facility }\end{array}$ & pre \\
\hline $\begin{array}{l}\text { Cazzato } \\
2001^{21}\end{array}$ & Italy & $\begin{array}{l}35 \text { family } \\
\text { paediatricians } \\
\text { in Southern } \\
\text { Italy }\end{array}$ & $\begin{array}{l}04- \\
06 / 1998\end{array}$ & prospectively & $\begin{array}{l}9917 \text { children } \\
\otimes 50 \%\end{array}$ & $\begin{array}{l}<12: \\
\leq 2: \\
40.5 \% \\
3-6: \\
33.5 \% \\
7-12: \\
26 \%\end{array}$ & $\begin{array}{l}\text { IN: every } \\
\text { patient-doctor } \\
\text { contact on an } \\
\text { index-day of } \\
\text { the week over } \\
\text { a 3-month } \\
\text { period }\end{array}$ & pre \\
\hline $\begin{array}{l}\text { Giannattasio } \\
2014^{22}\end{array}$ & Italy & $\begin{array}{l}3 \text { primary care } \\
\text { paediatricians' } \\
\text { practices in } \\
\text { Naples }\end{array}$ & $\begin{array}{l}\text { 12/2011- } \\
01 / 2012\end{array}$ & prospectively & $\begin{array}{l}284 \text { patients } \\
188 \\
\text { consultations } \\
\text { due to } \\
\text { symptoms } \\
\text { \ } 54 \%\end{array}$ & $\begin{array}{l}\varnothing 4.8 \\
0-2: 25 \% \\
\text { 3-5: } 36 \% \\
6-8: 20 \% \\
9-11: \\
13 \% \\
12-14: \\
6 \%\end{array}$ & $\begin{array}{l}\text { IN: all children } \\
\text { aged } 0-14 \\
\text { years observed } \\
\text { in the index } \\
\text { days }\end{array}$ & pre \\
\hline Hall 201723 & Australia & $\begin{array}{l}1 \text { Aboriginal- } \\
\text { owned and } \\
\text { operated } \\
\text { comprehensive } \\
\text { primary health- } \\
\text { care service }\end{array}$ & $\begin{array}{l}02 / 2013- \\
10 / 2015\end{array}$ & prospectively & $\begin{array}{l}121 \text { children } \\
\square 49 \%\end{array}$ & $\begin{array}{l}\text { 0: } 32.8 \% \\
1: 26.7 \% \\
2: 16.1 \% \\
3-4: \\
24.4 \% \\
\varnothing 18.4 \\
\text { months }\end{array}$ & $\begin{array}{l}\text { IN: children } \\
\text { presenting for } \\
\text { any reason, } \\
\text { aged < } 5 \text { years, } \\
\text { registered at } \\
\text { the health-care } \\
\text { service and } \\
\text { parent } \\
\text { willing/able to } \\
\text { complete } \\
\text { study } \\
\text { requirements } \\
\text { EX: family was } \\
\text { planning to } \\
\text { move from the } \\
\text { area in the } \\
\text { following } 12 \\
\text { months }\end{array}$ & pre \\
\hline $\begin{array}{l}\text { Harnden } \\
2006^{24}\end{array}$ & UK & $\begin{array}{l}18 \text { general } \\
\text { practices }\end{array}$ & $\begin{array}{l}10 / 2001- \\
05 / 2005\end{array}$ & prospectively & $\begin{array}{l}172 \text { patients } \\
\square 45 \%\end{array}$ & $\begin{array}{l}\emptyset 9.1 \\
\text { (positive } \\
\text { pertussis } \\
\text { serology) } \\
-9.8 \\
\text { (negative } \\
\text { pertussis } \\
\text { serology) }\end{array}$ & $\begin{array}{l}\text { IN: children, } \\
\text { aged } 5-16 \\
\text { years, with } \\
\text { cough } \geq 14 \\
\text { days } \\
\text { EX: refused } \\
\text { blood sample }\end{array}$ & $\begin{array}{l}\text { aet } \\
\text { prog }\end{array}$ \\
\hline
\end{tabular}




\begin{tabular}{|c|c|c|c|c|c|c|c|c|}
\hline Studies & Country & Setting & $\begin{array}{l}\text { Time of } \\
\text { recruit- } \\
\text { ment }\end{array}$ & $\begin{array}{l}\text { Data assess- } \\
\text { ment }\end{array}$ & $\begin{array}{l}\text { Study } \\
\text { population: } \\
\text { number } \\
\text { female }\end{array}$ & $\begin{array}{l}\text { Age in } \\
\text { study } \\
\text { sample } \\
\text { (years }^{1} \text { ) }\end{array}$ & $\begin{array}{l}\text { Inclusion (IN) / } \\
\text { Exclusion (EX) } \\
\text { criteria }\end{array}$ & $\begin{array}{l}\text { Out- } \\
\text { come }\end{array}$ \\
\hline $\begin{array}{l}\text { Krishnan } \\
201925\end{array}$ & USA & $\begin{array}{l}1 \\
\text { predominantly } \\
\text { suburban, } \\
\text { academic } \\
\text { paediatric } \\
\text { faculty } \\
\text { practice }\end{array}$ & 1 year & retrospectively & $\begin{array}{l}560 \\
\text { consultations } \\
\nabla 47 \%\end{array}$ & $\begin{array}{l}19 \text { days - } \\
18 \text { years } \\
\varnothing 6.6 \\
<2: 18 \% \\
2-5: 41 \%\end{array}$ & $\begin{array}{l}\text { IN: children } \\
\text { with } \\
\text { completed } \\
\text { electronic } \\
\text { health record } \\
\text { cough } \\
\text { template }\end{array}$ & aet \\
\hline $\begin{array}{l}\text { Leconte } \\
2011^{26}\end{array}$ & Belgium & $\begin{array}{l}36 \text { primary } \\
\text { care practices }\end{array}$ & $\begin{array}{l}02- \\
03 / 2006\end{array}$ & prospectively & 345 patients & n.r. & $\begin{array}{l}\text { IN: all } \\
\text { consulting } \\
\text { children aged } \\
5-17 \text { years }\end{array}$ & pre \\
\hline $\begin{array}{l}\text { Mash } 2012 \\
27\end{array}$ & $\begin{array}{l}\text { South } \\
\text { Africa }\end{array}$ & $\begin{array}{l}83 \text { primary } \\
\text { care clinics, } 17 \\
\text { mobile clinics, } \\
12 \text { community } \\
\text { health centres; } \\
\text { nurse-led with } \\
\text { support from } \\
\text { doctors }\end{array}$ & 1 year & prospectively & $\begin{array}{l}5545 \text { reasons } \\
\text { for encounter }\end{array}$ & $<1-14$ & $\begin{array}{l}\text { IN: all } \\
\text { ambulatory } \\
\text { patients aged } \\
0-14 \text { years } \\
\text { seen by health } \\
\text { workers }\end{array}$ & pre \\
\hline $\begin{array}{l}\text { Molony } \\
2016^{28}\end{array}$ & Ireland & $\begin{array}{l}1 \text { large general } \\
\text { practice with } 4 \\
\text { GPs in a } \\
\text { primary } \\
\text { healthcare } \\
\text { centre in North } \\
\text { Cork }\end{array}$ & $\begin{array}{l}10 / 2010- \\
10 / 2014\end{array}$ & retrospectively & $\begin{array}{l}5100 \\
\text { patients } \\
52572 \\
\text { consultations } \\
70489 \text { RFE }\end{array}$ & n.r. & $\begin{array}{l}\text { IN: doctor- } \\
\text { patient face-to- } \\
\text { face } \\
\text { encounters } \\
\text { (children aged } \\
<7 \text { years) on } \\
\text { all working } \\
\text { days and } 146 \\
\text { non-working } \\
\text { days with a } \\
\text { documentation } \\
\text { of diagnostic } \\
\text { code in the } \\
\text { electronic } \\
\text { medical record } \\
\text { EX: contacts } \\
\text { with practice } \\
\text { nurse/ } \\
\text { practice's } \\
\text { administrative } \\
\text { team, } \\
\text { telephone or } \\
\text { 'out-of-hours' } \\
\text { contacts }\end{array}$ & pre \\
\hline $\begin{array}{l}\text { Morrell } \\
1971 / 1972 \\
29,30\end{array}$ & UK & $\begin{array}{l}1 \text { general } \\
\text { practice with } 3 \\
\text { GPs }\end{array}$ & 1 year & prospectively & $\begin{array}{l}707 \text { patients } \\
4467 \\
\text { consultations } \\
\otimes 51.3 \%\end{array}$ & n.r. & $\begin{array}{l}\text { IN: new } \\
\text { patient- } \\
\text { initiated } \\
\text { consultations } \\
\text { with } \\
\text { symptoms not } \\
\text { presented to } \\
\text { any doctor in } \\
\text { the previous } \\
12 \text { months, } \\
\text { children aged } \\
0-14 \text { years } \\
\text { EX: doctor- } \\
\text { initiated } \\
\text { consultations }\end{array}$ & pre \\
\hline $\begin{array}{l}\text { Movsowitz } \\
1987^{31}\end{array}$ & $\begin{array}{l}\text { South } \\
\text { Africa }\end{array}$ & $\begin{array}{l}1 \text { private } \\
\text { paediatric } \\
\text { practice in } \\
\text { Cape Town }\end{array}$ & $\begin{array}{l}1984- \\
1985\end{array}$ & prospectively & 256 patients & $\begin{array}{l}3 \\
\text { months } \\
-15 \text { years }\end{array}$ & $\begin{array}{l}\text { IN: patients } \\
\text { with cough }>3 \\
\text { weeks }\end{array}$ & aet \\
\hline
\end{tabular}




\begin{tabular}{|c|c|c|c|c|c|c|c|c|}
\hline Studies & Country & Setting & $\begin{array}{l}\text { Time of } \\
\text { recruit- } \\
\text { ment }\end{array}$ & $\begin{array}{l}\text { Data assess- } \\
\text { ment }\end{array}$ & $\begin{array}{l}\text { Study } \\
\text { population: } \\
\text { number } \\
\text { female }\end{array}$ & $\begin{array}{l}\text { Age in } \\
\text { study } \\
\text { sample } \\
\text { (years }^{1} \text { ) }\end{array}$ & $\begin{array}{l}\text { Inclusion (IN) / } \\
\text { Exclusion (EX) } \\
\text { criteria }\end{array}$ & $\begin{array}{l}\text { Out- } \\
\text { come }\end{array}$ \\
\hline $\begin{array}{l}\text { NAMCS } \\
\text { Schappert } \\
1999^{32}\end{array}$ & USA & $\begin{array}{l}195 \text { office- } \\
\text { based } \\
\text { paediatricians }\end{array}$ & $\begin{array}{l}01 / 1995- \\
12 / 1996\end{array}$ & prospectively & $\begin{array}{l}92888 \\
\text { consultations } \\
\nabla 49.5 \%\end{array}$ & $\begin{array}{l}<15: \\
89.6 \% \\
15-24 \\
6.2 \% \\
25-44: \\
2.5 \% \\
45-64: \\
1.1 \%\end{array}$ & $\begin{array}{l}\text { IN: office visits } \\
\text { to non- } \\
\text { federally } \\
\text { employed } \\
\text { paediatricians } \\
\text { occurring } \\
\text { during a } \\
\text { randomly } \\
\text { assigned 1- } \\
\text { week reporting } \\
\text { period } \\
\text { EX: telephone } \\
\text { contacts and } \\
\text { visits made } \\
\text { outside the } \\
\text { physician's } \\
\text { office, visits to } \\
\text { government- } \\
\text { operated } \\
\text { facilities and } \\
\text { hospital-based } \\
\text { outpatient } \\
\text { departments }\end{array}$ & pre \\
\hline $\begin{array}{l}\text { Nizami } 1997 \\
33\end{array}$ & Pakistan & $\begin{array}{l}65 \text { GPs and } 29 \\
\text { paediatricians } \\
\text { in Karachi }\end{array}$ & $\begin{array}{l}04- \\
12 / 1992\end{array}$ & prospectively & $\begin{array}{l}2433 \\
\text { consultations }\end{array}$ & n.r. & $\begin{array}{l}\text { IN: children } \\
\text { aged }<5 \text { years }\end{array}$ & pre \\
\hline $\begin{array}{l}\text { Njalsson } \\
1992^{34}\end{array}$ & Iceland & $\begin{array}{l}12 \text { rural and } 4 \\
\text { urban primary } \\
\text { care health } \\
\text { centres }\end{array}$ & $\begin{array}{l}01- \\
12 / 1988\end{array}$ & prospectively & 67746 RFE & $0-14$ & $\begin{array}{l}\text { IN: all contacts } \\
\text { with children } \\
\text { aged } 0-14 \\
\text { years, } \\
\text { including } \\
\text { prescriptions, } \\
\text { follow-up } \\
\text { visits, tests, } \\
\text { procedures } \\
\text { and } \\
\text { administrative } \\
\text { visits }\end{array}$ & pre \\
\hline $\begin{array}{l}\text { SESAM } 2 \\
\text { Study Frese } \\
2011^{35}\end{array}$ & Germany & $\begin{array}{l}209 \text { GPs in the } \\
\text { federal state of } \\
\text { Saxony }\end{array}$ & $\begin{array}{l}\text { 10/1999- } \\
09 / 2000\end{array}$ & prospectively & $\begin{array}{l}805 \text { patients } \\
1196 \text { RFE }\end{array}$ & $\begin{array}{l}0-4: \\
13.3 \% \\
5-9: \\
14.7 \% \\
10-14: \\
20.8 \% \\
15-19: \\
51.2 \%\end{array}$ & $\begin{array}{l}\text { IN: randomly } \\
\text { selected } \\
\text { children, aged } \\
0-\leq 19 \text { years, } \\
\text { presenting in } \\
\text { general } \\
\text { practice (tenth } \\
\text { consultation of } \\
\text { the } \\
\text { consultation } \\
\text { hour) } \\
\text { previously } \\
\text { known to the } \\
\text { practitioner } \\
\text { EX: house } \\
\text { calls, patients } \\
\text { already } \\
\text { included in } \\
\text { SESAM } 2 \\
\text { study }\end{array}$ & pre \\
\hline $\begin{array}{l}\text { Simoes } \\
1997^{36}\end{array}$ & Ethiopia & $\begin{array}{l}3 \text { primary } \\
\text { health centres } \\
\text { with } 6 \\
\text { outpatient } \\
\text { clinic nurses }\end{array}$ & $\begin{array}{l}3 \text { weeks } \\
\text { in August }\end{array}$ & prospectively & $\begin{array}{l}449 \text { patients } \\
\square 54 \%\end{array}$ & $\begin{array}{l}2-11 \\
\text { months: } \\
36 \%\end{array}$ & $\begin{array}{l}\text { IN: any sick } \\
\text { child, aged } 2 \\
\text { months - } 5 \\
\text { years, } \\
\text { presenting } \\
\text { during study } \\
\text { hours }\end{array}$ & pre \\
\hline
\end{tabular}




\begin{tabular}{|c|c|c|c|c|c|c|c|c|}
\hline Studies & Country & Setting & $\begin{array}{l}\text { Time of } \\
\text { recruit- } \\
\text { ment }\end{array}$ & $\begin{array}{l}\text { Data assess- } \\
\text { ment }\end{array}$ & $\begin{array}{l}\text { Study } \\
\text { population: } \\
\text { number } \\
\text { female }\end{array}$ & $\begin{array}{l}\text { Age in } \\
\text { study } \\
\text { sample } \\
\text { (years }^{1} \text { ) }\end{array}$ & $\begin{array}{l}\text { Inclusion (IN) / } \\
\text { Exclusion (EX) } \\
\text { criteria }\end{array}$ & $\begin{array}{l}\text { Out- } \\
\text { come }\end{array}$ \\
\hline $\begin{array}{l}\text { TRANSITION } \\
\text { Okkes } 2002 \\
37\end{array}$ & Netherlands & $\begin{array}{l}54 \text { family } \\
\text { physicians in } \\
23 \text { locations in } \\
\text { the } \\
\text { Netherlands }\end{array}$ & $\begin{array}{l}1985- \\
1995\end{array}$ & prospectively & $\begin{array}{l}3371 \\
\text { episodes of } \\
\text { care }\end{array}$ & n.r. & $\begin{array}{l}\text { IN: episode } \\
\text { data for all } \\
\text { face-to-face } \\
\text { encounters } \\
\text { with } \\
\text { paediatricians' } \\
\text { listed patients, } \\
\text { aged 0-14 } \\
\text { years, } \\
\text { including } \\
\text { encounters for } \\
\text { prevention }\end{array}$ & aet \\
\hline $\begin{array}{l}\text { Usherwood } \\
1991^{38}\end{array}$ & UK & $\begin{array}{l}1 \text { general } \\
\text { practice in } \\
\text { Scotland }\end{array}$ & $\begin{array}{l}\text { 12/1986- } \\
01 / 1988\end{array}$ & prospectively & $\begin{array}{l}466 \\
\text { consultations } \\
\text { (including } \\
147 \text { home } \\
\text { visits) }\end{array}$ & n.r. & $\begin{array}{l}\text { IN: all health } \\
\text { centre } \\
\text { consultations } \\
\text { of children, } \\
\text { aged 2-13 } \\
\text { years }\end{array}$ & pre \\
\hline $\begin{array}{l}\text { Vinson } 1993 \\
39\end{array}$ & $\begin{array}{l}\text { USA, } \\
\text { Canada }\end{array}$ & $\begin{array}{l}44 \text { primary } \\
\text { care practices } \\
\text { in the } \\
\text { Ambulatory } \\
\text { Sentinel } \\
\text { Practice } \\
\text { Network } \\
\text { (ASPN) }\end{array}$ & $\begin{array}{l}\text { 10/1990- } \\
01 / 1991\end{array}$ & prospectively & $\begin{array}{l}1398 \\
\text { patients } \\
\square 47 \%\end{array}$ & $\begin{array}{l}\text { infancy - } \\
\leq 14 \\
\varnothing 4,8\end{array}$ & $\begin{array}{l}\text { IN: children } \\
\text { aged } 0-14 \\
\text { years with } \\
\text { cough } \leq 1 \\
\text { month }\end{array}$ & aet \\
\hline
\end{tabular}

$1=$ unless otherwise stated, aet = aetiology of the symptom cough in primary care, n.r.= not reported, pre = prevalence of the symptom cough in primary care, prog = prognosis of the symptom cough in primary care, resp.=respectively, RFE = reasons for encounter, $\Downarrow=f e m a l e$, $\emptyset=$ mean

Table 2: Prevalences of selected aetiologies, referring to children in consultation for a cough in primary care / paediatric practices sorted by duration of cough 


\begin{tabular}{|c|c|c|c|c|c|}
\hline Study & $\begin{array}{l}\text { Vinson } \\
1993\end{array}$ & $\begin{array}{l}\text { TRANSITION } \\
\text { Okkes } 2002\end{array}$ & $\begin{array}{l}\text { Krishnan } \\
2019\end{array}$ & $\begin{array}{l}\text { Harnden } \\
2006\end{array}$ & Movsowitz 1987 \\
\hline \multirow{2}{*}{ Study population } & & \multirow[t]{2}{*}{$\begin{array}{l}3371 \text { episodes } \\
\text { of care }\end{array}$} & & & \multirow{2}{*}{256 patients } \\
\hline & $\begin{array}{l}1398 \\
\text { patients }\end{array}$ & & $\begin{array}{l}560 \\
\text { consultations }\end{array}$ & $\begin{array}{l}172 \\
\text { patients }\end{array}$ & \\
\hline \multirow{2}{*}{$\begin{array}{l}\text { cough Duration of } \\
\text { Aetiology }\end{array}$} & acute & \multirow{2}{*}{\multicolumn{2}{|c|}{ all durations of cough }} & \multicolumn{2}{|c|}{ subacute/chronic } \\
\hline & $\leq 1$ month & & & $\begin{array}{l}\geq 2 \\
\text { weeks }\end{array}$ & $>3$ weeks \\
\hline \multirow{4}{*}{$\begin{array}{l}\text { Upper respiratory } \\
\text { tract infection }\end{array}$} & $n=873$ & $n=1294$ & $\mathrm{n}=241$ & n.r. & $n=71$ \\
\hline & $\begin{array}{l}62.4 \% \\
{[59.8 ; 65]}\end{array}$ & \multirow{3}{*}{$\begin{array}{l}38.4 \%[36.7 ; \\
40.1]\end{array}$} & \multirow[t]{3}{*}{$\begin{array}{l}43 \%[38.9 \\
47.3]\end{array}$} & & \\
\hline & $\begin{array}{l}\text { viral: } 35 \% \\
(n=494)\end{array}$ & & & & $\begin{array}{l}\text { (recurrent upper respiratory tract infection } \\
\text { including bronchiolitis and } \\
\text { bronchopneumonia) }\end{array}$ \\
\hline & $\begin{array}{l}\text { bacterial: } \\
27 \% \\
(n=379)\end{array}$ & & & & \\
\hline \multirow[t]{2}{*}{ Asthma } & $n=129$ & $n=100$ & $\mathrm{n}=101$ & n.r. & $n=129$ \\
\hline & $\begin{array}{l}9.2 \%[7.8 \\
10.9\}\end{array}$ & $3 \%[2.4 ; 3.6]$ & $\begin{array}{l}18 \%[15 \\
21.5]\end{array}$ & & $50.4 \%[44.1 ; 56.7]$ \\
\hline \multirow[t]{2}{*}{ Pertussis } & \multirow[t]{2}{*}{ n.r. } & $n=34$ & n.r. & $n=64$ & $n=56$ \\
\hline & & $1 \%[0.7 ; 1.4]$ & & $\begin{array}{l}37,2 \% \\
{[30.1} \\
44.9]\end{array}$ & $21.9 \%[17.1 ; 27.5]$ \\
\hline \multirow{3}{*}{$\begin{array}{l}\text { Bronchitis / } \\
\text { bronchiolitis }\end{array}$} & $\mathrm{n}=465$ & $n=757$ & $n=28$ & \multirow[t]{3}{*}{ n.r. } & \multirow[t]{3}{*}{ n.r. } \\
\hline & $\begin{array}{l}33.3 \% \\
{[30.8 ; 35.6]}\end{array}$ & $\begin{array}{l}22.5 \%[21.1 ; \\
23.9]\end{array}$ & $5 \%[3.4 ; 7.2]$ & & \\
\hline & & $\begin{array}{l}\text { (acute bronchitis } \\
\text { / bronchiolitis) }\end{array}$ & & & \\
\hline \multirow[t]{2}{*}{ Pharyngitis } & n.r. & n.r. & $\mathrm{n}=45$ & \multirow[t]{2}{*}{ n.r. } & \multirow[t]{2}{*}{ n.r. } \\
\hline & & & $8 \%[6 ; 10.7]$ & & \\
\hline \multirow[t]{2}{*}{ Sinusitis } & n.r. & $n=55$ & $n=45$ & \multirow[t]{2}{*}{ n.r. } & \multirow[t]{2}{*}{ n.r. } \\
\hline & & $1.6 \%[1.2 ; 2.1]$ & $8 \%[6 ; 10.7]$ & & \\
\hline \multirow[t]{2}{*}{ Laryngitis / tracheitis } & n.r. & $\mathrm{n}=245$ & n.r. & n.r. & n.r. \\
\hline & & $7.3 \%[6.4 ; 8.2]$ & & & \\
\hline \multirow[t]{2}{*}{ Croup } & $n=30$ & n.r. & $n=45$ & n.r. & n.r. \\
\hline & $\begin{array}{l}2.1 \%[1.5 \\
3.1]\end{array}$ & & $8 \%[6 ; 10.7 \%]$ & & \\
\hline \multirow[t]{2}{*}{ Pneumonia } & $n=78$ & $n=73$ & $n=39$ & n.r. & n.r. \\
\hline & $\begin{array}{l}5.6 \%[4.5 ; \\
6.9]\end{array}$ & $2.2 \%[1.7 ; 2.7]$ & $7 \%[5.1 ; 9.5]$ & & \\
\hline \multirow[t]{2}{*}{ Influenza } & n.r. & $n=43$ & n.r. & n.r. & n.r. \\
\hline & & $1.3 \%[0.9 ; 1.7]$ & & & \\
\hline \multirow[t]{2}{*}{ Otitis } & n.r. & $n=42$ & $n=28$ & n.r. & n.r. \\
\hline & & $1.2 \%[0.9 ; 1.7]$ & $5 \%[3.4 ; 7.2]$ & & \\
\hline \multirow{2}{*}{$\begin{array}{l}\text { Other allergic } \\
\text { diseases }\end{array}$} & $n=52$ & n.r. & n.r. & n.r. & n.r. \\
\hline & $\begin{array}{l}3.7 \%[2.8 ; \\
4.9]\end{array}$ & & & & \\
\hline
\end{tabular}




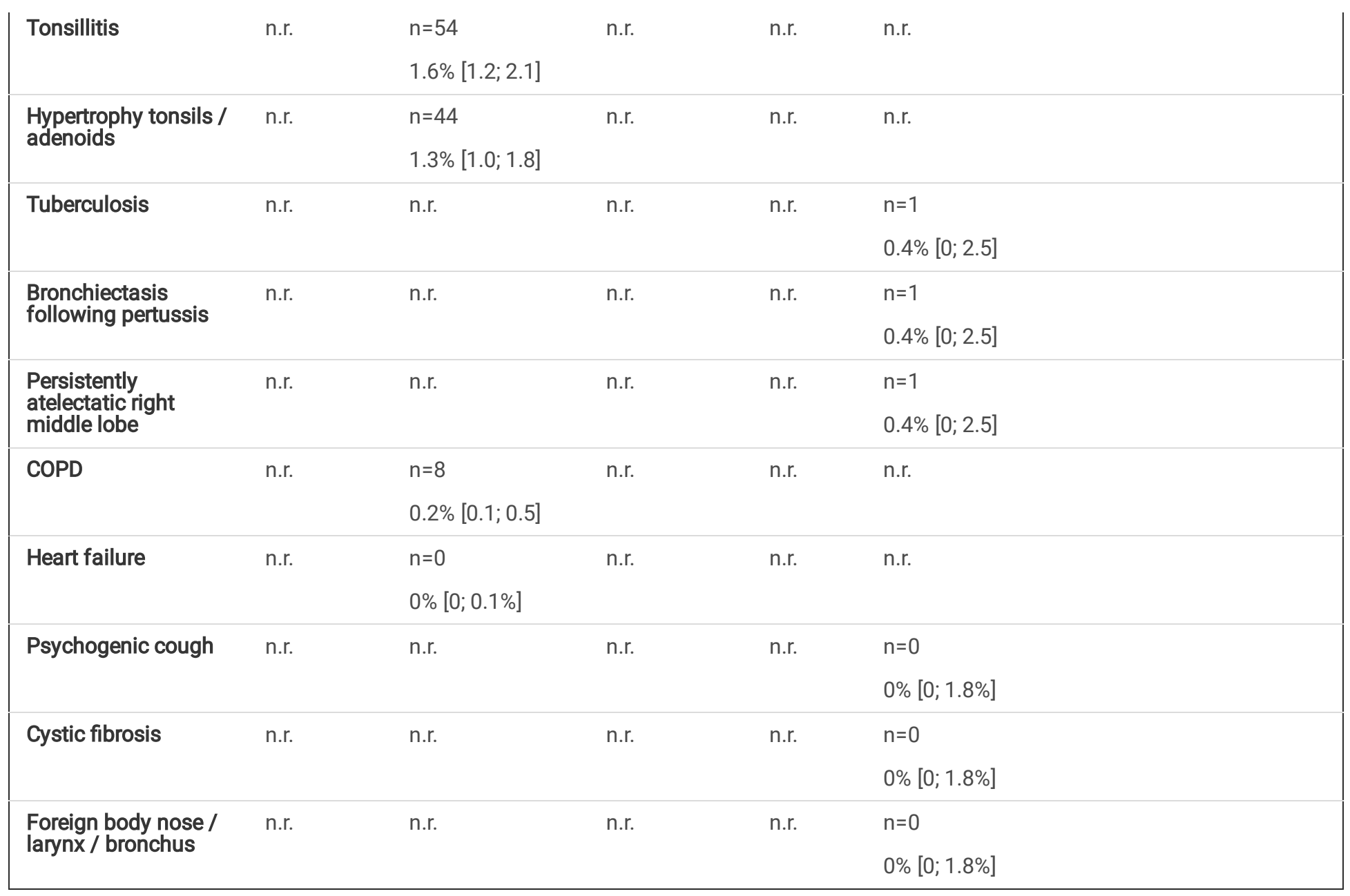

Every cell of table contains the absolute values (n), frequencies (\%) and confidence interval [] of the study population with the respective aetiology. COPD = chronic obstructive pulmonary disease, n.r.= not reported

\section{Figures}




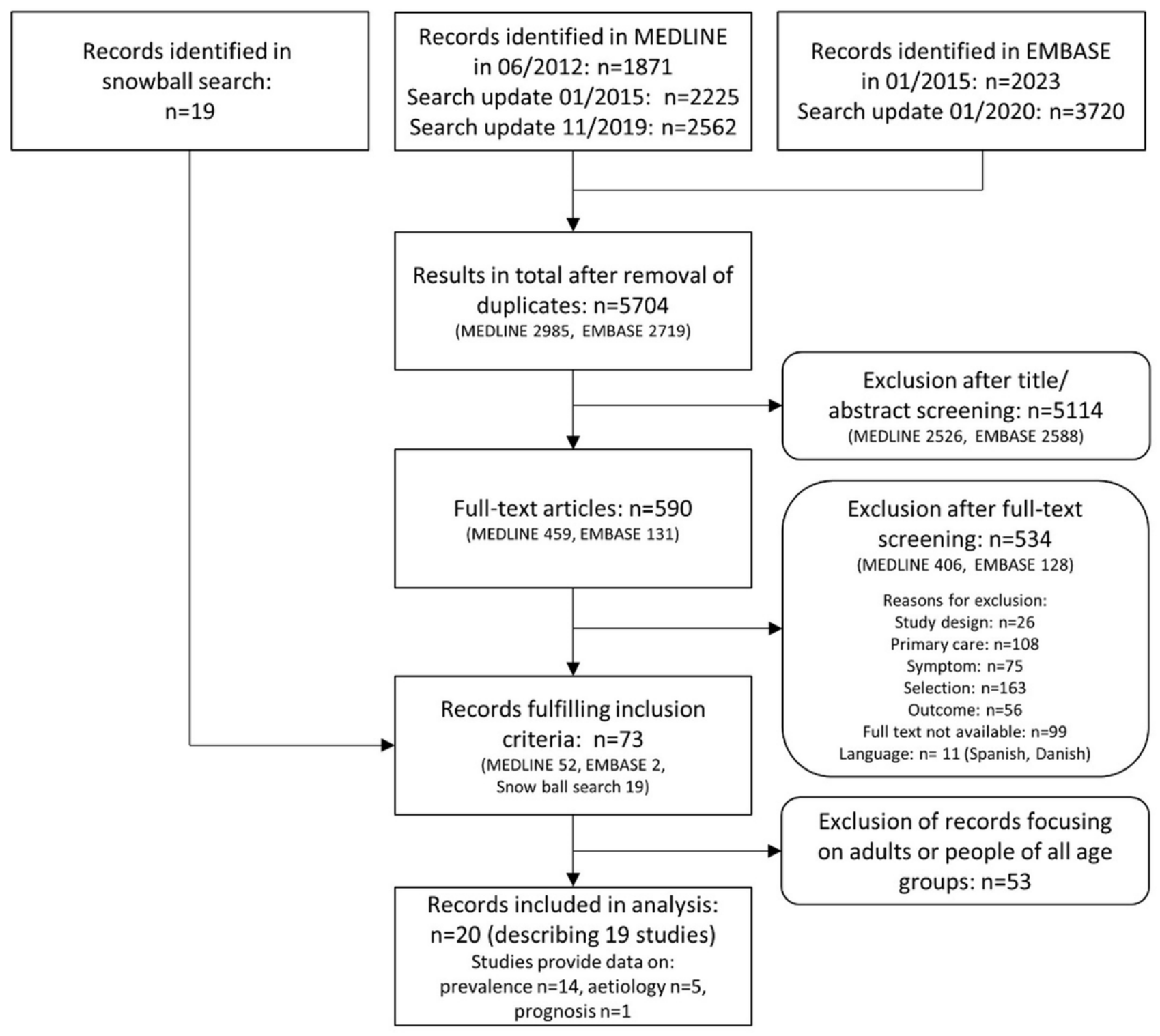

Figure 1

Search flow 


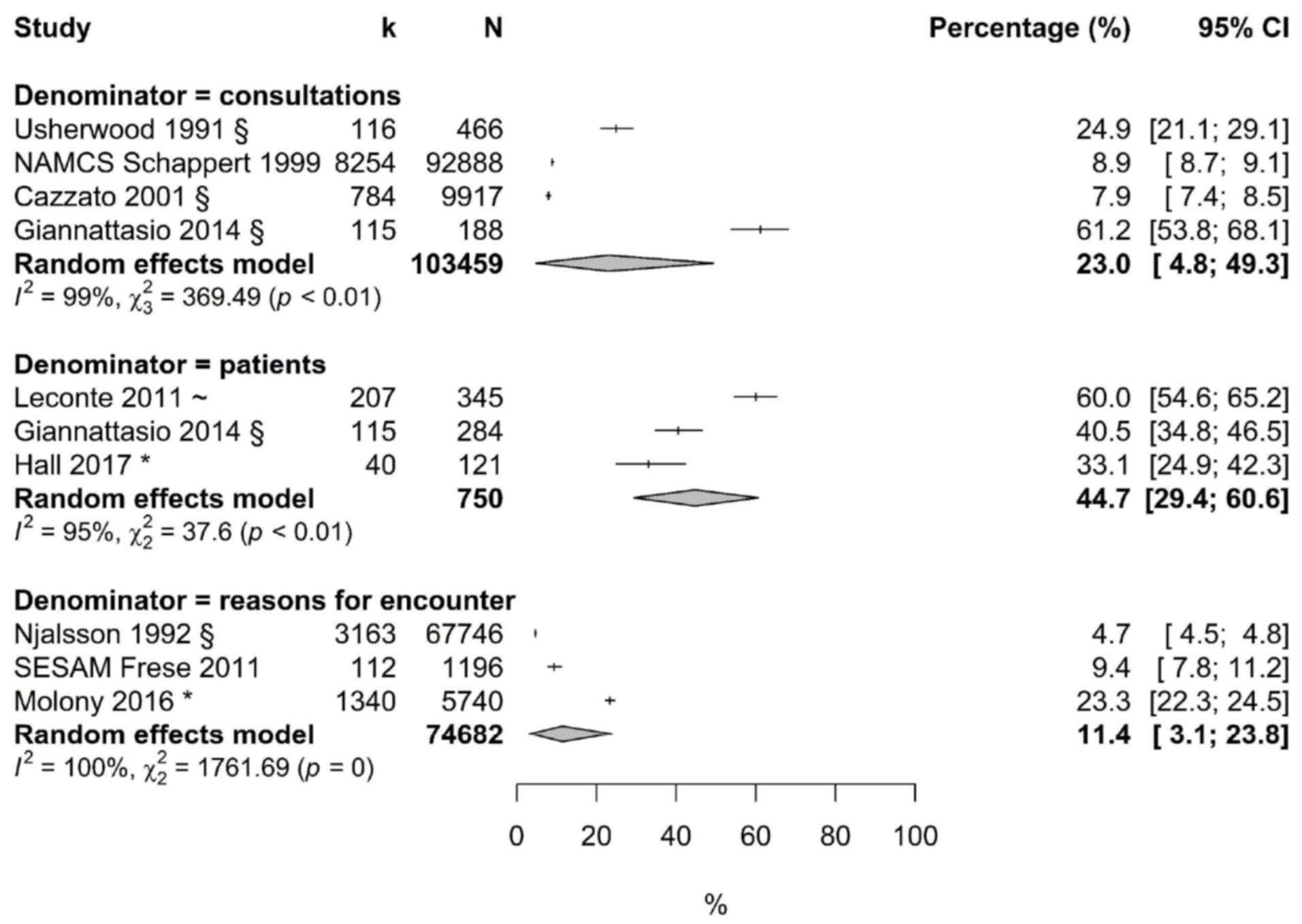

Figure 2

Prevalence of cough in children consulting in primary care of Western countries Meta-analysis: Prevalence of cough of all durations in children consulting in Western primary care, sorted by denominators. * = study included solely children $5-17$ years, $\mathrm{Cl}=$ confidence interval, $\mathrm{k}$ = number of consultations because of a cough / reasons for encounter because of a cough / patients in consultation for a cough, $\mathrm{N}=$ total number of consultations / reasons for encounter / patients in consultation

\section{Supplementary Files}

This is a list of supplementary files associated with this preprint. Click to download.

- BegmanncoughAdditionalfile1.docx

- BegmanncoughAdditionalfile2ad.docx

- BegmanncoughAdditionalfile3.docx

- BegmanncoughAdditionalfile4.docx 